\title{
Early Origins of Hypertension: Should Prevention Start Before Birth Using Natural Antioxidants?
}

\author{
Chien-Ning Hsu ${ }^{1,2}$ and You-Lin Tain ${ }^{3,4, *}$ \\ 1 Department of Pharmacy, Kaohsiung Chang Gung Memorial Hospital, Kaohsiung 833, Taiwan; \\ chien_ning_hsu@hotmail.com \\ 2 School of Pharmacy, Kaohsiung Medical University, Kaohsiung 807, Taiwan \\ 3 Department of Pediatrics, Kaohsiung Chang Gung Memorial Hospital and Chang Gung University College \\ of Medicine, Kaohsiung 833, Taiwan \\ 4 Institute for Translational Research in Biomedicine, Kaohsiung Chang Gung Memorial Hospital and Chang \\ Gung University College of Medicine, Kaohsiung 833, Taiwan \\ * Correspondence: tainyl@adm.cgmh.org.tw; Tel.: +886-975-056-995; Fax: +886-7733-8009
}

Received: 4 October 2020; Accepted: 21 October 2020; Published: 23 October 2020

\begin{abstract}
Hypertension may originate in early life. Reactive oxygen species (ROS) generated due to the exposure of adverse in utero conditions causes developmental programming of hypertension. These excessive ROS can be antagonized by molecules which are antioxidants. Prenatal use of natural antioxidants may reverse programming processes and prevent hypertension of developmental origin. In the current review, firstly we document data on the impact of oxidative stress in hypertension of developmental origin. This will be followed by effective natural antioxidants uses starting before birth to prevent hypertension of developmental origin in animal models. It will also discuss evidence for the common mechanisms underlying developmental hypertension and beneficial effects of natural antioxidant interventions used as reprogramming strategies. A better understanding of the reprogramming effects of natural antioxidants and their interactions with common mechanisms underlying developmental hypertension is essential. Therefore, pregnant mothers and their children can benefit from natural antioxidant supplementation during pregnancy in order to reduce their risk for hypertension later in life.
\end{abstract}

Keywords: antioxidant; arginine; developmental origins of health and disease (DOHaD); hypertension; melatonin; $N$-acetylcysteine; nitric oxide; oxidative stress; reactive oxygen species; resveratrol

\section{Introduction}

One in three adults across the globe have high blood pressure (BP), known as hypertension [1]. Despite recent advances in the treatment of hypertension, raised BP remains one of the leading causes of morbidity worldwide [2]. Growing evidence indicates that the origins of hypertension can begin in early life [3-5]. This theory, now called "developmental origins of health and disease $(\mathrm{DOHaD})$ ", is based on observing the developing fetus, if in utero exposed to an adverse environment, increases risk for developing adult diseases later in life [6]. In order to reduce the global burden of hypertension, we need to ascertain the mechanisms underlying the early origins of hypertension and provide strategies for early detection and intervention.

The imbalance between reactive oxygen species (ROS) production and antioxidants defense system causes oxidative stress and plays a pathophysiological role in fetal programming [7]. Cumulative evidence has shown that oxidative stress, experienced early in life, increases a later risk of hypertension [8-10]. Conversely, the use of antioxidant supplements during the period of developmental plasticity [10-12] may be beneficial in reversing the programming processes to prevent 
adult diseases, also known as reprogramming $[4,13]$. Therefore, this review aims to address the main scientific findings on the interplay among oxidative stress, natural antioxidants, and developmental programming in hypertension.

Particular interest in this review is that we highlighted the use of natural antioxidants as reprogramming strategies, in order to prevent developmental hypertension via reversing programming processes. The PubMed/MEDLINE database was used to identify related peer-reviewed journal articles published in English. Additional studies were selected based on references from eligible articles. We used different combinations of keywords as follows: "antioxidants", "hypertension", "blood pressure", "developmental programming", "DOHaD", "free radicals", "offspring", "melatonin", "mother", "nitric oxide", "oxidative stress", "pregnancy", "progeny", "reprogramming", "reactive oxygen species", "reactive nitrogen species", "resveratrol", and "vitamin". The last search was conducted on 15 September 2020.

\section{Oxidative Stress and Developmental Programming of Hypertension}

\subsection{Oxidative Stress in Pregnancy}

Fetal oxygen requirements vary throughout pregnancy [7]. During the first trimester, fetal oxygen levels are low. Low physiological oxygen tension is required for early differentiation and organogenesis. The increased oxygen levels that occur as a result of the establishment of the fetal-placental circulation allows rapid gain of fetal weight during the second and third trimesters [14]. Many maternal conditions cause increased oxidative stress, such as diabetes, obesity, preeclampsia, and smoking [7,8]. Accordingly, ROS plays dual behavior in pregnancy, as produced at high level negatively affects fetal development while moderate amount is essential to allow for the normal embryonic and fetal growth [7].

The formation of superoxide anion $\left(\mathrm{O}_{2}^{-}\right)$leads to a cascade of other ROS, like hydrogen peroxide $\left(\mathrm{H}_{2} \mathrm{O}_{2}\right)$ and hydroxyl anion $\left(\mathrm{OH}^{-}\right)$. Several enzymes such as nicotinamide adenine dinucleotide phosphate (NADPH) oxidases, xanthine oxidase, cyclo-oxygenases, and lipoxygenases can produce superoxide radical [15]. Superoxide radical can also be generated by uncoupled nitric oxide synthases (NOS) in certain conditions, like inhibition by asymmetric dimethylarginine (ADMA) [16]. Generally, NOS produces nitric oxide (NO), a free radical, as well as a vasodilator. The NO has dual role in pregnancy which depends on its concentration. High levels of NO can interact with superoxide to form peroxynitrite $\left(\mathrm{ONOO}^{-}\right)$, a most injurious reactive nitrogen species (RNS) with pronounced deleterious effects. Conversely, maintained physiological level of $\mathrm{NO}$ is required during healthy normal pregnancy [17]. The excessive ROS can be neutralized by enhancing defense antioxidant system, including superoxide dismutase (SOD), catalase, glutathione peroxidase (GPx), and glutathione reductase (GR) [18]. In compromised pregnancy, oxidative damage occurs because of the failure of defensive antioxidant mechanisms to respond to the excessive ROS, leading to DNA damage, lipid peroxidation, protein modification, and mitochondrial dysfunction [18]. These processes are involved in the pathogenesis of developmental programming of hypertension. The main pathways producing ROS/RNS and key defensive antioxidant enzymatic systems are illustrated in Figure 1. 


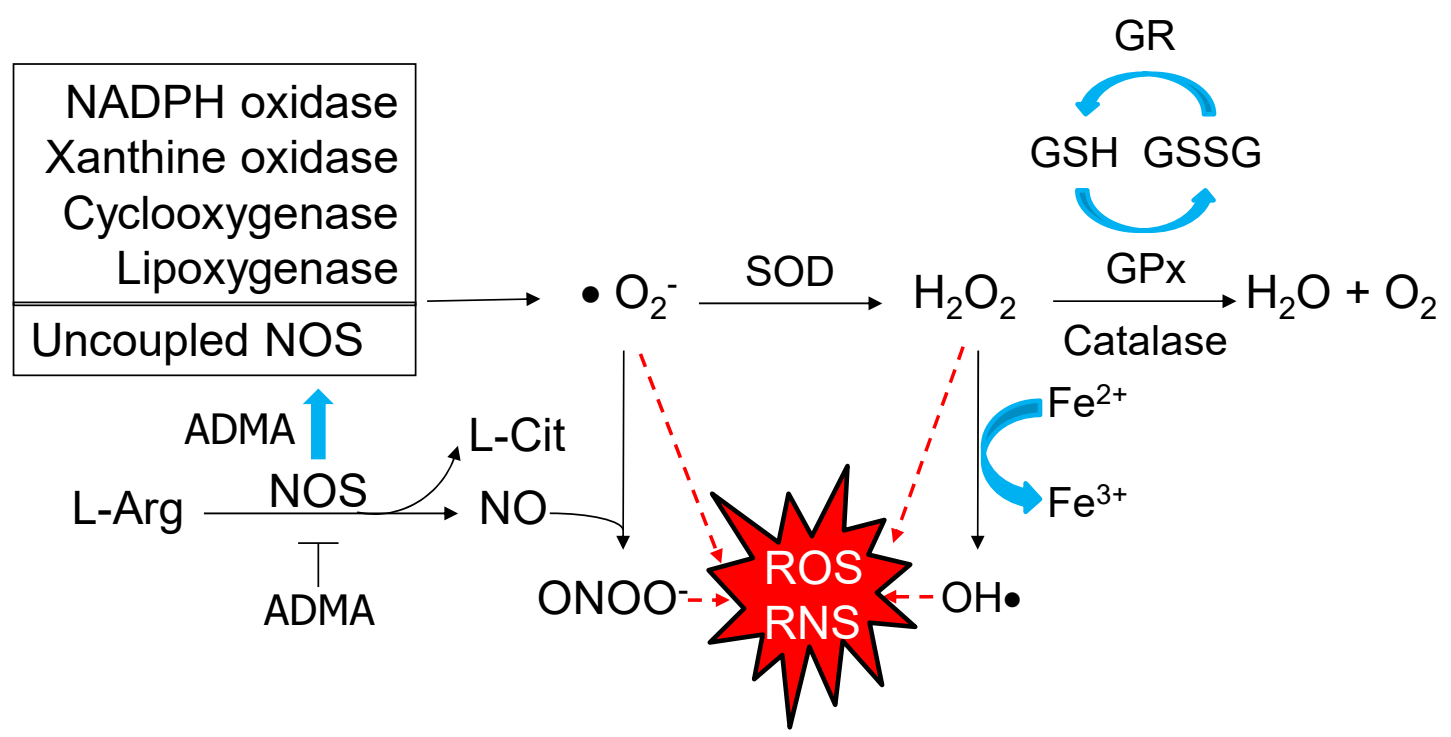

Figure 1. Schematic representation of the pathways producing reactive oxygen species (ROS)/reactive nitrogen species (RNS) and key defensive antioxidant enzymatic systems. Several enzymes produce superoxide radical $\left(\mathrm{O}_{2}{ }^{-}\right)$, such as NADPH oxidase, xanthine oxidase, cyclo-oxygenase, lipoxygenase, and uncoupled nitric oxide synthase (NOS). NOS catalyzes L-arginine (L-Arg) to produce nitric oxide (NO) and L-citrulline (L-Cit). While being inhibited by asymmetric dimethylarginine (ADMA), uncoupled NOS generates superoxide instead of NO. High level of NO can interact with superoxide to form peroxynitrite $\left(\mathrm{ONOO}^{-}\right)$. Red dashed arrow lines indicate $\mathrm{O}_{2}{ }^{-}$, hydrogen peroxide $\left(\mathrm{H}_{2} \mathrm{O}_{2}\right)$, hydroxyl anion $\left(\mathrm{OH}^{-}\right)$, and peroxynitrite $\left(\mathrm{ONOO}^{-}\right)$are key elements of ROS/RNS. Conversely, excessive ROS/RNS can be counterbalanced by various antioxidant enzymes, such as superoxide dismutase (SOD), catalase, glutathione peroxidase (GPx), and glutathione reductase (GR). GPx converts reduced glutathione (GSH) into oxidized glutathione (GSSG). The generated GSSG is reduced to GSH with consumption of NADPH by GR.

\subsection{Developmental Programming of Hypertension}

Important support for the developmental programming of hypertension came from human and experimental studies. Several risks associated with high BP of offspring have been identified in mother-child cohorts, including maternal undernutrition [19], maternal obesity [20], short term breastfeeding [21], maternal smoking [22], gestational hypertension [23], low vitamin D consumption [24], and excessive postnatal weight gain [25]. A meta-analysis of 1342 preterm or very low birth weight (VLBW) and 1738 full term individuals reported that those born preterm or VLBW have modestly higher BP later in life [26].

Although, human observational studies cannot establish direct cause-and-effect relationships between adverse maternal environmental factors and offspring hypertension, where emerging evidence from animal studies have confirmed the types of prenatal insults that drive disease programming and identify potential mechanisms. As previously reviewed by us and others [5,27-29], maternal malnutrition, maternal illness like diabetes, perinatal hypoxia, environmental chemicals, toxins, and the use of medication in pregnancy have all been reported to affect developmental programming and increase the risk for developing hypertension in adulthood.

Current evidence suggests that there may be common mechanisms underlying hypertension of developmental origin. Animal models have provided significant insight into the molecular mechanisms, such as oxidative stress, dysregulation of the renin-angiotensin system (RAS), impaired nutrient-sensing signals, NO deficiency, and gut microbiota dysbiosis [5,27-29]. Among them, oxidative stress plays a crucial role and is closely linked to other important mechanisms involved in programmed hypertension (Figure 2). 


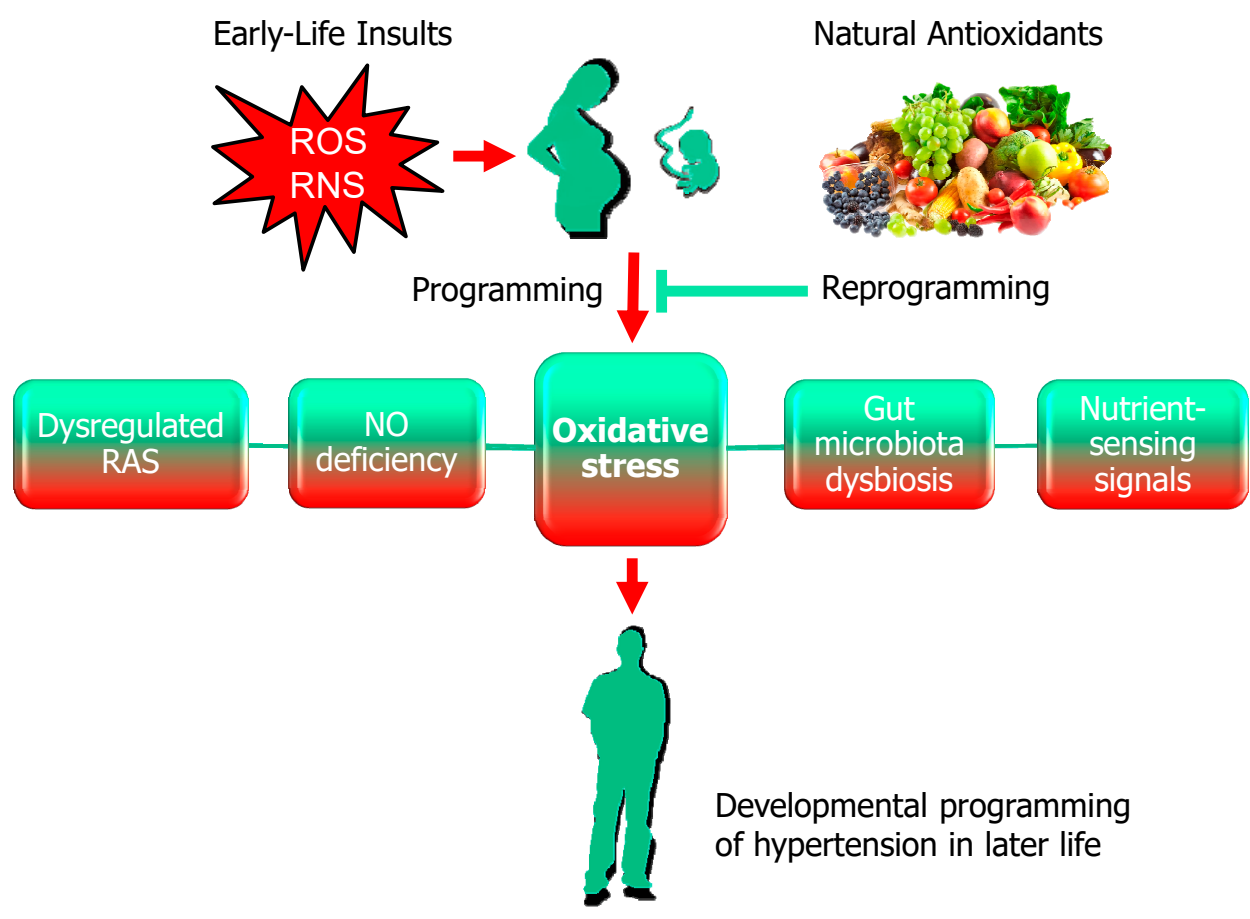

Figure 2. Schematic illustration of the impact of oxidative stress and natural antioxidants on hypertension of developmental origin. Red arrow indicates early-life insults in pregnancy causes increased reactive oxygen species (ROS)/reactive nitrogen species (RNS) and fetal programming, consequently resulting in hypertension in adult offspring. Oxidative stress acts as a central hub through which mechanisms contributing to programming hypertension are interconnected. These mechanisms include dysregulated the renin-angiotensin system (RAS), nitric oxide (NO) deficiency, gut microbiota dysbiosis, and impaired nutrient-sensing signals. Conversely, natural antioxidants can serve as reprogramming strategies to reverse the programmed processes and prevent the developmental programming of hypertension, which is indicated by green T-bar lines.

\subsection{The Impact of Oxidative Stress in Hypertension of Developmental Origin}

Several lines of evidence support the role of oxidative stress in the developmental programming of hypertension. First, cumulative evidence indicates that hypertension, programmed by various early-life insults, are associated with oxidative stress, as reviewed elsewhere $[5,10]$. These adverse perinatal environmental conditions include maternal caloric restriction [30], maternal diabetes [31], maternal nicotine exposure [32], ethanol consumption [33], preeclampsia [34], high-fat diet [35], high-fructose consumption [36], high-salt diet [37], methyl-donor diet [38], iron deficient diet [39], zinc deficient diet [40], magnesium deficient diet [41], prenatal glucocorticoid exposure [42], prenatal hypoxia [43], and exposure to environmental chemicals [44,45]. Second, there are reports that ADMA levels, a NOS inhibitor and ROS inducer, are associated with the elevation of BP in various developmental animal models $[30,31,34]$. Conversely, early interventions lowering ADMA levels and restoring NO-ROS balance can protect adult offspring against hypertension [10]. Another line of evidence comes from studies of antioxidant system and oxidative stress damage markers. Our previous study reported that adult offspring born to dams that have received low protein diet developed hypertension, which was associated with decreased antioxidant glutathione level and increased 8-isoprostaglandin F2 $\alpha$ level (a biomarker of lipid peroxidation) [46]. Maternal high-fat diet caused raised BP in adult offspring related to increased malondialdehyde levels together with decreased antioxidant enzyme activities of SOD, GPx, and catalase [47]. Additionally, increased oxidative DNA damage marker 8-hydroxydeoxyguanosine (8-OHdG) expression has been reported in several models of programmed hypertension $[35,38,48]$. Together these observations indicate that oxidative stress is an important pathogenetic link for hypertension of developmental origin. 


\section{Natural Antioxidants}

\subsection{Natural Antioxidants and Hypertension}

Antioxidants can be categorized as enzymatic antioxidants and nonenzymatic antioxidants. The human body protects itself from the harmful effects of ROS by using enzymatic antioxidants to modulate the free radical reactions. There are two non-enzymatic antioxidants, the natural antioxidants and the synthetic antioxidants [49]. Given that the scope of this article is limited to the natural antioxidants, we will not discuss the synthetic antioxidants.

Natural antioxidants are mainly coming from plants, such as vegetables, fruits, nuts, and seeds. Antioxidants obtained from vegetables and fruits are mainly phenolic compounds, and the most important are the polyphenols, vitamins, minerals, and flavonoids [50]. Therefore, dietary sources are very important since they can be easily used for dietary interventions.

Randomized clinical trials employing nonpharmacological dietary interventions emphasizing dietary antioxidant nutrients have shown notable BP-lowering results in hypertensive and normotensive subjects [51-53]. The dietary components in these studies are high in compounds known as natural antioxidants. As reviewed elsewhere [54], these commonly used antioxidants include Vitamins A, $\mathrm{C}$ and E, L-arginine, flavonoids, coenzyme Q10, $\beta$-carotene, and $\alpha$-lipoic acid. However, so far specific natural antioxidants are not yet recommended for antihypertensive therapy due to lack of target specificity, lack of understanding of action mechanisms, and potential interindividual variability in therapeutic efficacy [54]. Additionally, melatonin [55], resveratrol [56], and N-acetylcysteine [57] all have shown antihypertensive effects through antioxidant mechanisms counterbalancing excessive ROS. Some of the natural antioxidants that have been isolated from various natural sources are shown in the Table 1.

Table 1. Different sources of natural antioxidants.

\begin{tabular}{|c|c|c|}
\hline Antioxidants & Natural Sources & References \\
\hline Vitamin A & Meat, fish, fruits, and vegetables & [58] \\
\hline Vitamin C & Most fruits and some vegetables, particularly citrus fruits, and tomatoes & {$[59,60]$} \\
\hline Vitamin E & Vegetables oils, nuts, broccoli, and fish & {$[60,61]$} \\
\hline L-arginine & Meat, dairy products, eggs, nuts, and seeds & [62] \\
\hline Flavonoids & $\begin{array}{l}\text { Potatoes, tomatoes, lettuce, onions, wheat, dark chocolate, concord grapes, } \\
\text { and black tea }\end{array}$ & {$[60,61]$} \\
\hline$\alpha$-lipoic acid & Yeast, organ meats, spinach, broccoli, and potatoes & [63] \\
\hline$\beta$-carotene & Kale, red paprika, spinach, parsley, tomatoes, and carrots & [64] \\
\hline Coenzyme Q10 & Wheat bran, fish, and organ meats & {$[60,64]$} \\
\hline Melatonin & Eggs, meat, fish, milk, nuts, seeds, cereals, peppers, tomatoes, and mushrooms & [65] \\
\hline Resveratrol & Grapes, peanuts, cocoa, soy, and berries & [66] \\
\hline$N$-acetylcysteine & Chicken, turkey, garlic, yogurt, and eggs & [67] \\
\hline
\end{tabular}

\subsection{Natural Antioxidants as Reprogramming Interventions}

Despite dietary and nutritional supplements during pregnancy and lactation have been recommended for improving maternal and newborn health and survival [68,69]. Little is known on whether supplementing with specific natural antioxidants, starting before birth, can be beneficial on hypertension programmed by adverse maternal conditions in humans. Here, we summarize the knowledge available today regarding natural antioxidants used as reprogramming strategies for developmental hypertension in various animal models [30,31,38,44,70-98], all of which are listed in Table 2. We restricted this review to natural antioxidants applied only during pregnancy and/or lactation which are critical periods for reprogramming strategies to prevent the development of 
hypertension. So far, many natural antioxidants have shown benefits on prevention of developmental hypertension, such as amino acids, vitamins and minerals, melatonin, resveratrol, and $\mathrm{N}$-acetylcysteine. In this review, rats are the commonly used small animal models. Rats develop rapidly during infancy and reach sexual maturity at approximately 5-6 weeks of age. In adulthood, one human year almost equals two rat weeks [99]. Accordingly, Table 2 lists the outcomes determined in rats ranging from 4 to 50 weeks of rat age, which allows calculations to extract data for the specific age group that can be translated to humans. However, very limited information is available regarding large animals to study the role of natural antioxidants on hypertension of developmental origin. 
Table 2. Animal models dealing with natural antioxidants for hypertension reprogramming.

\begin{tabular}{|c|c|c|c|c|c|c|}
\hline Natural Antioxidants & Animal Models & Intervention Period & $\begin{array}{l}\text { Species/ } \\
\text { Gender }\end{array}$ & $\begin{array}{c}\text { Age at BP } \\
\text { Determination (week) }\end{array}$ & Beneficial Effects & Ref. \\
\hline \multicolumn{7}{|c|}{ Amino acids } \\
\hline $3 \%$ L-glycine in chow & Maternal low protein diet & Pregnancy and lactation & Wistar/M & 4 & $\begin{array}{c}\text { Prevented } \\
\text { hypertension }\end{array}$ & [70] \\
\hline $0.25 \%$ L-citrulline in drinking water & Maternal STZ-induced diabetes & Pregnancy and lactation & $\mathrm{SD} / \mathrm{M}$ & 12 & $\begin{array}{c}\text { Prevented } \\
\text { hypertension }\end{array}$ & [31] \\
\hline $0.25 \%$ L-citrulline in drinking water & $\begin{array}{l}\text { Maternal L-NAME } \\
\text { exposure }\end{array}$ & Pregnancy and lactation & $\mathrm{SD} / \mathrm{M}$ & 12 & $\begin{array}{c}\text { Prevented } \\
\text { hypertension }\end{array}$ & [71] \\
\hline $0.25 \%$ L-citrulline in drinking water & $\begin{array}{l}\text { Prenatal dexamethasone } \\
\text { exposure }\end{array}$ & Pregnancy and lactation & $\mathrm{SD} / \mathrm{M}$ & 12 & $\begin{array}{c}\text { Prevented } \\
\text { hypertension }\end{array}$ & [72] \\
\hline $0.25 \%$ L-citrulline in drinking water & Genetic hypertension & $\begin{array}{l}2 \text { weeks before until } 6 \\
\text { weeks after birth }\end{array}$ & SHR/M \& F & 50 & $\begin{array}{c}\text { Prevented } \\
\text { hypertension }\end{array}$ & [73] \\
\hline $\begin{array}{l}3 \% \text { L-taurine in drinking } \\
\text { water }\end{array}$ & $\begin{array}{l}\text { Maternal highsugar } \\
\text { diet }\end{array}$ & Pregnancy and lactation & $\mathrm{SD} / \mathrm{F}$ & 8 & $\begin{array}{c}\text { Prevented } \\
\text { hypertension }\end{array}$ & [74] \\
\hline $\begin{array}{l}3 \% \text { L-taurine in drinking } \\
\text { water }\end{array}$ & Maternal STZ-induced diabetes & Pregnancy and lactation & Wistar/M \& F & 16 & $\begin{array}{c}\text { Prevented } \\
\text { hypertension }\end{array}$ & [75] \\
\hline $\begin{array}{l}\text { L-tryptophan } 200 \mathrm{mg} / \mathrm{kg} \text { BW/day via } \\
\text { oral gavage }\end{array}$ & $\begin{array}{l}\text { Maternal adenosine-induced } \\
\text { CKD }\end{array}$ & Pregnancy & $\mathrm{SD} / \mathrm{M}$ & 12 & $\begin{array}{c}\text { Prevented } \\
\text { hypertension }\end{array}$ & [76] \\
\hline BCAA-supplemented diets & $\begin{array}{l}\text { Maternal caloric } \\
\text { Restriction }\end{array}$ & Pregnancy & $\mathrm{SD} / \mathrm{M}$ & 16 & $\begin{array}{c}\text { Prevented } \\
\text { hypertension }\end{array}$ & [77] \\
\hline \multicolumn{7}{|c|}{ Amino acids plus vitamins } \\
\hline L-arginine, L-taurine, Vitamins $\mathrm{C}$ and $\mathrm{E}$ & Genetic hypertension & $\begin{array}{l}2 \text { weeks before until } 8 \\
\text { weeks after birth }\end{array}$ & SHR/M\& F & 9 & $\begin{array}{c}\text { Prevented } \\
\text { hypertension }\end{array}$ & [78] \\
\hline L-arginine, L-taurine, Vitamins $\mathrm{C}$ and $\mathrm{E}$ & Genetic hypertension & $\begin{array}{l}2 \text { weeks before until } 4 \\
\text { weeks after birth }\end{array}$ & $\mathrm{FHH} / \mathrm{M} \& \mathrm{~F}$ & 36 & $\begin{array}{c}\text { Prevented } \\
\text { hypertension }\end{array}$ & [79] \\
\hline L-arginine, L-taurine, Vitamins $\mathrm{C}$ and $\mathrm{E}$ & Genetic hypertension & $\begin{array}{l}2 \text { weeks before until } 8 \\
\text { weeks after birth }\end{array}$ & SHR/M \& F & 50 & $\begin{array}{c}\text { Prevented } \\
\text { hypertension }\end{array}$ & [80] \\
\hline
\end{tabular}


Table 2. Cont.

\begin{tabular}{|c|c|c|c|c|c|c|}
\hline Natural Antioxidants & Animal Models & Intervention Period & $\begin{array}{l}\text { Species/ } \\
\text { Gender }\end{array}$ & $\begin{array}{c}\text { Age at BP } \\
\text { Determination (week) }\end{array}$ & Beneficial Effects & Ref. \\
\hline \multicolumn{7}{|c|}{ Vitamins } \\
\hline Vitamin C, E, folic acid and selenium & $\begin{array}{l}\text { Maternal caloric } \\
\text { Restriction }\end{array}$ & Pregnancy & $\begin{array}{l}\text { Wistar/ } \\
\text { M \& F }\end{array}$ & 16 & $\begin{array}{c}\text { Prevented } \\
\text { hypertension }\end{array}$ & [81] \\
\hline Vitamin C 350 mg/kg/day i.p. daily & $\begin{array}{l}\text { Prenatal LPS } \\
\text { Exposure }\end{array}$ & Gestational day 8 to 14 & $\mathrm{SD} / \mathrm{M}$ & 12 & $\begin{array}{c}\text { Prevented } \\
\text { hypertension }\end{array}$ & [82] \\
\hline $5 \mathrm{mg} / \mathrm{kg}$ folate in chow & $\begin{array}{l}\text { Maternal } \\
\text { low protein } \\
\text { diet }\end{array}$ & Pregnancy & Wistar/M & 15 & $\begin{array}{c}\text { Prevented } \\
\text { hypertension }\end{array}$ & [83] \\
\hline$\alpha$-tocopherol $350 \mathrm{mg} / \mathrm{kg} /$ day via gavage & $\begin{array}{l}\text { Prenatal LPS } \\
\text { Exposure }\end{array}$ & Gestational day 13 to 20 & Wistar/M & 28 & $\begin{array}{c}\text { Prevented } \\
\text { hypertension }\end{array}$ & [84] \\
\hline \multicolumn{7}{|c|}{ Melatonin } \\
\hline $0.01 \%$ melatonin in drinking water & Maternal caloric restriction & Pregnancy and lactation & $\mathrm{SD} / \mathrm{M}$ & 12 & $\begin{array}{c}\text { Prevented } \\
\text { hypertension }\end{array}$ & [30] \\
\hline $0.01 \%$ melatonin in drinking water & Maternal methyl-donor diet & Pregnancy and lactation & $\mathrm{SD} / \mathrm{M}$ & 12 & $\begin{array}{c}\text { Attenuated } \\
\text { hypertension }\end{array}$ & [38] \\
\hline $0.01 \%$ melatonin in drinking water & Maternal constant light exposure & Pregnancy and lactation & $\mathrm{SD} / \mathrm{M}$ & 12 & $\begin{array}{c}\text { Prevented } \\
\text { hypertension }\end{array}$ & [85] \\
\hline $0.01 \%$ melatonin in drinking water & Maternal L-NAME exposure & Pregnancy and lactation & $\mathrm{SD} / \mathrm{M}$ & 12 & $\begin{array}{c}\text { Prevented } \\
\text { hypertension }\end{array}$ & [86] \\
\hline $0.01 \%$ melatonin in drinking water & Maternal high-fructose diet & Pregnancy and lactation & $\mathrm{SD} / \mathrm{M}$ & 12 & $\begin{array}{c}\text { Prevented } \\
\text { hypertension }\end{array}$ & [87] \\
\hline $0.01 \%$ melatonin in drinking water & $\begin{array}{l}\text { Maternal high-fructose diet plus } \\
\text { post-weaning high-salt diet }\end{array}$ & Pregnancy and lactation & $\mathrm{SD} / \mathrm{M}$ & 12 & $\begin{array}{c}\text { Attenuated } \\
\text { hypertension }\end{array}$ & [88] \\
\hline $0.01 \%$ melatonin in drinking water & $\begin{array}{c}\text { Prenatal dexamethasone } \\
\text { exposure }\end{array}$ & Pregnancy and lactation & $\mathrm{SD} / \mathrm{M}$ & 16 & $\begin{array}{c}\text { Prevented } \\
\text { hypertension }\end{array}$ & [89] \\
\hline $0.01 \%$ melatonin in drinking water & $\begin{array}{l}\text { Prenatal dexamethasone } \\
\text { exposure plus post-weaning } \\
\text { high-fat diet }\end{array}$ & Pregnancy and lactation & $\mathrm{SD} / \mathrm{M}$ & 16 & $\begin{array}{c}\text { Prevented } \\
\text { hypertension }\end{array}$ & [90] \\
\hline $\begin{array}{l}\text { Melatonin } 10 \mathrm{mg} / \mathrm{kg} \mathrm{BW} / \text { day in } \\
\text { drinking water }\end{array}$ & Genetic hypertension model & Pregnancy & $\mathrm{SHR} / \mathrm{M}$ & 16 & $\begin{array}{c}\text { Prevented } \\
\text { hypertension }\end{array}$ & [91] \\
\hline
\end{tabular}


Table 2. Cont.

\begin{tabular}{|c|c|c|c|c|c|c|}
\hline Natural Antioxidants & Animal Models & Intervention Period & $\begin{array}{l}\text { Species/ } \\
\text { Gender }\end{array}$ & $\begin{array}{c}\text { Age at BP } \\
\text { Determination (week) }\end{array}$ & Beneficial Effects & Ref. \\
\hline \multicolumn{7}{|c|}{ Resveratrol } \\
\hline $50 \mathrm{mg} / \mathrm{L}$ resveratrol in drinking water & $\begin{array}{c}\text { Maternal plus post-weaning } \\
\text { high-fructose diet }\end{array}$ & Pregnancy and lactation & $\mathrm{SD}$ rat/M & 12 & $\begin{array}{c}\text { Prevented } \\
\text { hypertension }\end{array}$ & [92] \\
\hline $50 \mathrm{mg} / \mathrm{L}$ resveratrol in drinking water & $\begin{array}{l}\text { Maternal bisphenol A exposure } \\
\text { and high-fat diet }\end{array}$ & Pregnancy and lactation & $\mathrm{SD}$ rat $/ \mathrm{M}$ & 16 & $\begin{array}{c}\text { Prevented } \\
\text { hypertension }\end{array}$ & [44] \\
\hline $0.05 \%$ resveratrol in drinking water & $\begin{array}{c}\text { Maternal TCDD and } \\
\text { dexamethasone exposures }\end{array}$ & Pregnancy and lactation & $\mathrm{SD}$ rat $/ \mathrm{M}$ & 16 & $\begin{array}{c}\text { Prevented } \\
\text { hypertension }\end{array}$ & [45] \\
\hline $50 \mathrm{mg} / \mathrm{L}$ resveratrol in drinking water & $\begin{array}{l}\text { Maternal L-NAME plus } \\
\text { postnatal high-fat diet }\end{array}$ & Pregnancy and lactation & $\mathrm{SD}$ rat $/ \mathrm{M}$ & 16 & $\begin{array}{c}\text { Attenuated } \\
\text { hypertension }\end{array}$ & [93] \\
\hline $4 \mathrm{~g} / \mathrm{kg}$ diet resveratrol & Genetic hypertension model & Pregnancy and lactation & SHR/M \& F & 20 & $\begin{array}{c}\text { Prevented } \\
\text { hypertension }\end{array}$ & [94] \\
\hline \multicolumn{7}{|c|}{$\mathrm{N}$-acetylcysteine (NAC) } \\
\hline $1 \% \mathrm{NAC}$ in drinking water & $\begin{array}{l}\text { Suramin-induced } \\
\text { preeclampsia }\end{array}$ & Pregnancy and lactation & $\mathrm{SD} / \mathrm{M}$ & 12 & $\begin{array}{c}\text { Prevented } \\
\text { hypertension }\end{array}$ & [34] \\
\hline $1 \% \mathrm{NAC}$ in drinking water & $\begin{array}{l}\text { Maternal L-NAME } \\
\text { exposure }\end{array}$ & Pregnancy and lactation & $\mathrm{SD} / \mathrm{M}$ & 12 & $\begin{array}{c}\text { Prevented } \\
\text { hypertension }\end{array}$ & [84] \\
\hline $1 \% \mathrm{NAC}$ in drinking water & $\begin{array}{c}\text { Prenatal } \\
\text { dexamethasone } \\
\text { and postnatal } \\
\text { high-fat diet }\end{array}$ & Pregnancy and lactation & $\mathrm{SD} / \mathrm{M}$ & 12 & $\begin{array}{c}\text { Prevented } \\
\text { hypertension }\end{array}$ & [95] \\
\hline $1 \% \mathrm{NAC}$ in drinking water & Genetic hypertension model & Pregnancy and lactation & SHR/M & 12 & $\begin{array}{c}\text { Prevented } \\
\text { hypertension }\end{array}$ & [96] \\
\hline NAC $500 \mathrm{mg} / \mathrm{kg} /$ day in drinking water & $\begin{array}{l}\text { Maternal } \\
\text { nicotine } \\
\text { exposure }\end{array}$ & $\begin{array}{l}\text { Gestational day } 4 \text { to } \\
\text { postnatal day } 10\end{array}$ & $\mathrm{SD} / \mathrm{M}$ & 32 & $\begin{array}{c}\text { Prevented } \\
\text { hypertension }\end{array}$ & [32] \\
\hline \multicolumn{7}{|c|}{ Others } \\
\hline Conjugated linoleic acid & Maternal high-fat diet & Pregnancy and lactation & $\mathrm{SD} / \mathrm{M}$ & 18 & $\begin{array}{c}\text { Attenuated } \\
\text { hypertension }\end{array}$ & [97] \\
\hline Fish oil & Maternal low protein diet & $\begin{array}{l}\text { Pregnancy and } 10 \text { days } \\
\text { after birth }\end{array}$ & Wistar/M \&F & 25 & $\begin{array}{c}\text { Prevented } \\
\text { hypertension }\end{array}$ & {$[98]$} \\
\hline
\end{tabular}

Studies tabulated according to types of natural antioxidant, animal models and age at measure. STZ = streptozotocin. L-NAME $=\mathrm{N}^{\mathrm{G}}$-nitro-L-arginine-methyl ester. $\mathrm{CKD}=$ chronic kidney disease. BCAA = branched-chain amino acid. LPS = lipopolysaccharide. TCDD = 2,3,7,8-tetrachlorodibenzo-p-dioxin. SD = Sprague-Dawley rat. SHR = spontaneously hypertensive rat. $\mathrm{FHH}=$ Fawn hooded hypertensive rat. $\mathrm{M}=$ male $\mathrm{F}=$ female 


\subsection{Amino Acids}

Several amino acids have antioxidant properties [100]. Some of them have been reported to regulate BP [101]. L-glycine supplementation during pregnancy and lactation was shown to protect against maternal low-protein intake-induced programmed hypertension in offspring [70], which agrees well with a previous study demonstrating that glycine administration produced depressor responses on BP [100].

A decreased NO bioavailability is one of the pathogenetic mechanisms underlying hypertension of developmental origin [102]. Both L-arginine (the substrate for NO synthase) and L-citrulline, a precursor of L-arginine, can be supplemented to increase NO production [103]. As shown in Table 2, perinatal L-citrulline supplementation had a beneficial effect on offspring BP in a variety of animal models, including maternal streptozotocin (STZ)-induced diabetes [31], Maternal $\mathrm{N}^{\mathrm{G}}$-nitro-L-arginine methyl ester (L-NAME) exposure [71], and prenatal dexamethasone exposure [72]. In spontaneously hypertensive rats (SHR), perinatal supplementation with L-citrulline can prevent the transition from prehypertension to hypertension via restoration of NO bioavailability [73]. However, whether L-arginine supplementation in pregnancy alone is associated with these beneficial effects has not been clarified.

Additionally, L-taurine has been used alone or combined with other antioxidants to prevent hypertension programmed by a variety of early-life insults [74,75,78-80]. L-taurine is a common sulfur-containing amino acid [104]. Several beneficial effects of L-taurine on hypertension have been reported, including regulation of $\mathrm{NO}$ and hydrogen sulfide $\left(\mathrm{H}_{2} \mathrm{~S}\right)$, regulation of the renin-angiotensin system (RAS), and reduction of oxidative stress $[105,106]$. Perinatal L-taurine use showed protection in hypertension programmed by maternal high-sugar consumption or maternal STZ-induced diabetes [74,75]. A combination of L-taurine, L-arginine, and Vitamins $C$ and $E$ therapy in the perinatal period caused a reduction of BP in SHRs and in Fawn hooded hypertensive rats (FHH), two genetic models of hypertension [78-80]. Furthermore, other amino acids, like L-tryptophan [76] and branched-chain amino acids (BCAAs) [77], have been used as reprogramming interventions, by which hypertension could be prevented in adult offspring. Despite amino acids with antioxidant properties have been increasingly investigated for their reprogramming benefits on hypertension of developmental origin, there is still an unmet need in better understanding the accurate dietary recommendations for these amino acids for pregnant women in normal and compromised pregnancy.

\subsection{Vitamins}

Vitamin C, E, folic acid and selenium, which showed a beneficial effect on BP in established hypertension [107], were also considered as potential protective compounds against hypertension of developmental origin. Vitamins $C$ and $E$ are the most frequently used antioxidant vitamins. Vitamin $C$ is a six-carbon lactone with the ability of ROS quenching. Vitamin E ( $\alpha$-Tocopherol) is a fat-soluble carotenoid that inhibits NADPH oxidase, lipoxygenase, and cyclooxygenase [108]. Gestational use of Vitamin C or E alone protected the elevation of BP in adult male offspring exposed to prenatal lipopolysaccharide (LPS) [82,84]. Also, the combined supplementation of vitamins C, E, folic acid, and selenium can prevent hypertension programmed by maternal caloric restriction [81]. Moreover, maternal supplementation with folic acid can prevent offspring against hypertension in a maternal low protein diet model [83].

However, The Cochrane Collaboration compiled 56 clinical trials that included almost a quarter million participants to conclude that $\beta$-carotene, vitamin $\mathrm{E}$, and high doses of vitamin $\mathrm{A}$ seem to increase mortality [109]. Although excessive dietary vitamin A intake has been associated with birth defects in humans [110], whether excessive vitamin supplementation affects hypertension reprogramming remains largely unknown. 


\subsection{Melatonin}

Melatonin, an endogenous indoleamine derived from tryptophan, has pleiotropic biofunctions, such as antioxidant, anti-inflammation, regulation of circadian rhythm, epigenetic regulation, and fetal development [111-115]. As reviewed elsewhere [12], melatonin has emerged as a common reprogramming strategy to prevent many adult diseases in different models of developmental programming. Several mechanisms, including reduction of oxidative stress, restoration of NO, epigenetic regulation, and rebalancing the RAS have been associated with the reprogramming effects of melatonin [12].

As an antioxidant, not only melatonin but also its metabolites have abilities to scavenge ROS and RNS [115]. Table 2 shows perinatal melatonin therapy prevents hypertension programmed by diverse early-life insults, such as maternal caloric restriction [30], maternal methyl-donor diet [38], maternal constant light exposure [85], maternal L-NAME exposure [86], high-fructose diet [87], high-fructose diet plus post-weaning high-salt diet [88], prenatal dexamethasone exposure [89], and prenatal dexamethasone exposure plus post-weaning high-fat diet [90]. Additionally, maternal melatonin therapy can prevent the transition from prehypertension to hypertension in SHRs [91]. The protective effects of maternal melatonin therapy against hypertension are associated with increased NO bioavailability $[30,38,87,88]$, reduced ADMA levels [30,88], decreased 8-OHdG expression [38], and decreased 8-isoprostane level [86]. Together, these findings emphasize that melatonin works as an antioxidant in different ways to benefit hypertension reprogramming.

So far, serious adverse events are scarce in humans receiving melatonin treatment ranged from $0.3 \mathrm{mg}$ to $1600 \mathrm{mg}$ daily $[112,116,117]$. Although, melatonin has a generally favorable safety profile, no clinical trials of melatonin in pregnant women have been identified to assess its use and safety. A previous study demonstrated that pregnant sheep received a high dose of melatonin and its levels were raised up to 200 times normal values, leading to no adverse effect on fetal health [118]. It is noteworthy that maternal melatonin treatment can cause long-term transcriptomic changes and regulate numerous biological pathways [113]. Whether these programmed processes and pathways might be interconnected with its antioxidant mechanism to prevent programmed hypertension remains to be elucidated.

\subsection{Resveratrol}

Polyphenols include anthocyanins, flavonoids, and stilbenes [50]. Resveratrol is a natural polyphenol from the stilbene family that occurs as a phytoalexin [119]. Resveratrol constitutes functional foods with many health benefits [120]. Resveratrol exerts pleiotropic functions including anti-inflammatory and antioxidant properties, improvement of endothelial function, anti-atherosclerotic and anti-obesogenic effect, anticarcinogenic activity, and restoring bioavailable NO production [121]. The antioxidant effects of resveratrol include ROS/RNA scavenging ability, enhancement of various antioxidant defensive enzymes, induction of glutathione level, increases of NO bioavailability, and activation of nuclear factor-erythroid 2-related factor 2 (Nrf2) [122,123].

Currently, many human studies have reported that resveratrol is a well-tolerated and safe supplement $[121,122,124]$. However, others have shown toxic effects of resveratrol in vitro and in vivo [125]. Resveratrol appears to have a hormetic effect where resveratrol like an antioxidant at low doses are associated with beneficial effects, while a pro-oxidant at high doses usually have a toxic effect [126]. However, limited data are available regarding the effects of resveratrol supplementation during pregnancy on offspring's health [123].

Table 2 indicates reprogramming effects of maternal resveratrol therapy on offspring's hypertension in rats ranging from 12 to 20 weeks of age [44,45,82-84]. However, its long-term effect on offspring outcome remains largely unknown. In a maternal combined bisphenol A exposure and high-fat diet model, the protective effects of maternal resveratrol treatment against offspring hypertension are associated with increased NO bioavailability and decreased renal 8-OHdG expression [38]. Similarly, perinatal resveratrol use can restore the balance between ROS and NO to protect against hypertension 
in adult offspring born to dams exposed to combined TCDD and dexamethasone administration [45], high-fructose diet [92], and L-NAME plus postnatal high-fat diet [93]. Additionally, the high BP in adult SHRs can also be prevented by resveratrol supplementation in pregnancy and lactation [94].

\subsection{N-Acetylcysteine}

$\mathrm{N}$-acetylcysteine (NAC), a plant antioxidant naturally found in onion, is a precursor to glutathione [127]. NAC is also a stable L-cysteine analogue and can be a precursor for $\mathrm{H}_{2} \mathrm{~S}$ synthesis. $\mathrm{H}_{2} \mathrm{~S}$ is a gaseous signaling molecule with antihypertensive properties [128]. Accordingly, NAC has been reported to prevent hypertension in human trials and experimental studies $[129,130]$. As shown in Table 2, the beneficial effects of maternal NAC therapy on hypertension reprogramming have been reported in a variety of animal models, including maternal nicotine exposure [32], suramin-induced pre-eclampsia [34], L-NAME exposure [84], and prenatal dexamethasone and postnatal high-fat diet [95]. In a prenatal dexamethasone and postnatal high-fat diet model, the beneficial effects of NAC against offspring hypertension were linked to an increase in plasma glutathione level and $\mathrm{H}_{2} \mathrm{~S}$-generating enzymes, and reduction of oxidative stress [95]. In another study, perinatal use of NAC also protected offspring against hypertension programmed by maternal L-NAME exposure via increases of H2S-generating enzymes and activity in offspring kidneys [84]. Moreover, maternal NAC therapy prevented programmed hypertension in adult offspring born to suramin-treated females was associated with increased glutathione levels, restoration of $\mathrm{NO}$ and $\mathrm{H}_{2} \mathrm{~S}$ pathways [34].

\subsection{Others}

Conjugated linoleic acid (CLA), a functional lipid with hypotensive and antioxidant activity, have attracted increasing interest recently for its health benefits [131]. One report demonstrated that perinatal CLA supplementation attenuated hypertension programmed by maternal high-fat consumption in adult male offspring [96]. Fish oil is a dietary source of omega-3 polyunsaturated fatty acids, which act like an antioxidant with health benefits [132]. Although current evidence suggests that mega-3 polyunsaturated fatty acid could prevent the rise in BP in hypertensive subjects [133], only one study reported that maternal fish oil supplementation was capable of protecting adult offspring against hypertension programmed by maternal low protein diet [97]. Regardless of BP-lowering effects of supplementing natural antioxidants in lactation, such as melinjo (Gnetum gnemon) seed extract [134], grape skin extract [47], and 15-deoxy- $\Delta 12,14$-prostaglandin J2 (15d-PGJ2) [48], have been reported, all of them have not yet been examined in pregnancy.

It is noteworthy that keeping a physiological oxidative-antioxidative balance is advised to prevent hypertension of developmental origin. Excess antioxidants may shift oxidative stress to an opposite state of "antioxidant stress" [135]. Therefore, a critical balance of antioxidants intake needs to be assessed for the clinical situation to avoid their adverse effects. The intake of natural antioxidant supplements would only make sense in a case of deficits, trying to restore their levels, but not as a usual intake [136].

\section{Protective Role of Natural Antioxidants on Common Mechanisms Involved in Programmed Hypertension}

The primordial studies in animal models with controlled interventions provided important results revealing potential protective mechanisms of natural antioxidants against developmental hypertension. These beneficial mechanisms of natural antioxidants on programmed hypertension include restoration of ADMA-NO pathway, rebalancing of the RAS, activation of nutrient-sensing signals, and reshaping gut microbiota (Figure 2).

\subsection{Restoration of ADMA-NO Pathway}

ADMA-induced NO-ROS imbalance is involved in the development of hypertension, while restoration of the ADMA-NO balance has been considered a potential reprogramming strategy 
for hypertension of developmental origin [101,137]. Due to multiple metabolic fates, L-arginine is not considered as a good NO precursor [101]. Unlike L-arginine, L-citrulline can bypass hepatic metabolism and it is not a substrate of arginase. As we mentioned earlier, maternal supplementing with L-citrulline can protect adult offspring against the developmental programming of hypertension via restoration of NO bioavailability in several animal models [31,71-73].

Additionally, several natural antioxidants have been reported to lower ADMA levels and restore NO-ROS balance in human and experimental studies [101,137,138]. These antioxidants include vitamin $\mathrm{E}$, salvianolic acid A, melatonin, resveratrol, $\mathrm{N}$-acetylcysteine, oxymatrine, and epigallocatechin-3-gallate. However, only few ADMA-lowering antioxidants have been examined for prevention of hypertension in the developmental programming models, like resveratrol [92,93], melatonin [85-87], and NAC [34,84]. Similar to programming hypertension models, melatonin [139] and NAC [140] have been revealed to prevent the development of hypertension in SHRs by decreasing plasma ADMA levels. Currently, however, a specific ADMA-lowering antioxidant is not available in clinical practice. A therapeutic approach to restore bioavailable NO production by lowering ADMA, thereby preventing the development of hypertension still awaits further evaluation.

\subsection{Rebalancing of the Renin-Angiotensin System}

RAS is a coordinated hormonal cascade in the regulation of BP. The classical RAS comprises the angiotensin converting enzyme (ACE)-Ang II-angiotensin type 1 receptor (AT1R) axis that promotes the elevation of BP. Pharmacological therapies based on the blockade of classical RAS are used extensively for the treatment of hypertension [141]. Emerging evidence supports the theory that dysregulated RAS is a common mechanism underlying programmed hypertension [10,13,142]. Conversely, early blockade of the classical RAS can reprogram inappropriate activation of the RAS, thereby prevention of developmental hypertension [143,144].

Several lines of evidence support that rebalancing the RAS by natural antioxidants has impact on developmental hypertension. First, one report demonstrated that resveratrol therapy protected adult offspring against hypertension programmed by maternal plus post-weaning high-fat diet. Its protective effects were associated with increased plasma Ang (1-7) level and decreased plasma Ang II level [145]. Secondly, maternal L-NAME exposure-induced increases of renal renin and ACE expression was prevented by maternal NAC therapy [84]. Thirdly, there are studies showing that the beneficial effects of melatonin are related to increased ACE2 level. ACE2 belongs to the non-classical RAS pathway, which appears to antagonize the effects of the classical RAS [141]. A previous study from our laboratory examined the maternal caloric restriction-induced hypertension model and found maternal melatonin therapy protected offspring against hypertension, which is related to increased renal ACE2 expression [30]. Likewise, melatonin therapy was reported to prevent the development of offspring's hypertension was associated with increased ACE2 level in a maternal light exposure model [85]. Last, adult male offspring exposed to prenatal dexamethasone exposure and postnatal high-fat diet developed hypertension; this was associated with increased oxidative stress and activation of the classical RAS [146]. However, Nrf2 activation therapy in pregnancy not only prevented the rising BP but also reduced oxidative stress and downregulated the classical RAS concurrently [146].

\subsection{Activation of Nutrient-Sensing Signals}

Nutrient-sensing signaling pathways are commonly deregulated in fetal development and programmed hypertension, as reviewed elsewhere [10]. Cyclic adenosine monophosphate (AMP)-activated protein kinase (AMPK), silent information regulator T1 (SIRT1), peroxisome proliferator-activated receptors (PPARs), and PPAR $\gamma$ coactivator-1 $\alpha$ (PGC- $1 \alpha$ ), are well-known nutrient-sensing signals [147].

Nutrient-sensing signals regulate PPARs and their target genes, consequently leading to developmental hypertension [148]. There are several PPAR target genes, such as Sod2, Nos2, Nos3, and Nrf2, involved in oxidative stress [149]. A variety of early-life insults can downregulate 
nutrient-sensing signals, to induce hypertension of developmental origin. These adverse in utero environmental conditions include maternal methyl donor diet [38], maternal high-fructose plus post-weaning high-salt diets [88], high-fructose diet [92], high-fat diet [150], and maternal L-NAME exposure and post-weaning high-fat diet [93]. Conversely, interventions activating the AMPK/SIRT1/PGC-1 $\alpha$ pathway has shown beneficial on hypertension reprogramming [151]. Because nutrient-sensing signals are interconnected with redox regulation, AMPK plays an important role in regulating antioxidant defense during oxidative stress [151]. The reprogramming effects against hypertension by gestational supplementation of natural antioxidants, such as melatonin [88] and resveratrol [93] were related to upregulate several nutrient-sensing signals.

\subsection{Reshaping Gut Microbiota}

Gut microbiota regulates the cellular redox state within the host organism. In the gut, microbes-mediated ROS production in low levels maintains gut homeostasis, whereas high levels of ROS lead to oxidative stress damage [152]. On the other hand, gut microbe-mediated therapies have been applied as a therapeutic approach for several oxidative stress-associated diseases [153].

Early-life gut microbiota dysbiosis adversely affects fetal programming and may have a long-range negative influence on adult health outcomes [154]. The gut microbiota produces a variety of metabolites, including antioxidant vitamins [155]. Gut microbiota dysbiosis has been linked to hypertension related to several mechanisms, including alterations of microbial metabolites, activation of the RAS, inhibition of NO, increased sympathetic activity, and mediation of the $\mathrm{H}_{2} \mathrm{~S}$ signaling pathway [156].

Emerging evidence supports the notion that gut microbiota dysbiosis in early-life is correlated with hypertension of developmental origin $[76,86,96,150,157,158]$. Dietary fiber intake for modulating the microbiota has become one dietary strategy. Our recent reports showed that prebiotic inulin (i.e., a special form of dietary fiber) supplementation during pregnancy and lactation can protect offspring against hypertension programmed by maternal high-fructose or high-fat consumption $[157,158]$. Another study from our laboratory examined the high-fat diet-induced hypertension model and found that modulation of gut microbiota by resveratrol can protect adult offspring against programmed hypertension and oxidative stress concurrently [44]. Although, recent studies have demonstrated that probiotics and prebiotics have antioxidants property $[152,153,159]$, their roles in oxidative stress-related hypertension of developmental origin, especially their use in pregnancy, require further investigation.

Together, natural antioxidant interventions in pregnancy may reprogram common mechanisms to prevent offspring against hypertension of developmental origin. However, these effects await further efforts to bridge gaps between basic animal research and clinical translation.

\section{Conclusions}

This review recapitulates that the use of effective natural antioxidants starting before birth protects adult offspring against hypertension in various animal models of developmental programming. However, natural antioxidants can also be disadvantageous. Yet, at the same time, we are aware that a long road still lies ahead in determining the right dose of natural antioxidant for the right person, at the right time, for clinical applications. Further research will help to better delineate the mechanisms underlying developmental hypertension by which these processes occur, and whether specific natural antioxidant therapies are implemented in humans to obviate the global burden of hypertension.

Author Contributions: C.-N.H.: contributed to concept generation, data interpretation, drafting of the manuscript, critical revision of the manuscript and approval of the article; Y.-L.T.: contributed to concept generation, data interpretation, drafting of the manuscript, critical revision of the manuscript and approval of the article. All authors have read and agreed to the published version of the manuscript.

Funding: This work was supported by grants CMRPG8J0252, CMRPG8K0141, and CMRPG8J0891 from Chang Gung Memorial Hospital, Kaohsiung, Taiwan.

Conflicts of Interest: The authors declare no conflict of interest. 


\section{References}

1. Bromfield, S.; Muntner, P. High blood pressure: The leading global burden of disease risk factor and the need for worldwide prevention programs. Curr. Hypertens. Rep. 2013, 15, 134-136. [CrossRef] [PubMed]

2. Lozano, R.; Naghavi, M.; Foreman, K.; Lim, S.; Shibuya, K.; Aboyans, V.; Abraham, J.; Adair, T.; Aggarwal, R.; Ahn, S.Y.; et al. Global and regional mortality from 235 causes of death for 20 age groups in 1990 and 2010: A systematic analysis for the Global Burden of Disease Study 2010. Lancet 2012, 380, 2095-2128. [CrossRef]

3. Luyckx, V.A.; Bertram, J.F.; Brenner, B.M.; Fall, C.; Hoy, W.E.; Ozanne, S.E.; Vikse, B.E. Effect of fetal and child health on kidney development and long-term risk of hypertension and kidney disease. Lancet 2013, 382, 273-283. [CrossRef]

4. Paauw, N.D.; van Rijn, B.B.; Lely, A.T.; Joles, J.A. Pregnancy as a critical window for blood pressure regulation in mother and child: Programming and reprogramming. Acta Physiol. 2017, 219, 241-259. [CrossRef]

5. Hsu, C.N.; Tain, Y.L. The double-edged sword effects of maternal nutrition in the developmental programming of hypertension. Nutrients 2018, 10, 1917. [CrossRef]

6. Hanson, M.; Gluckman, P. Developmental origins of noncommunicable disease: Population and public health implications. Am. J. Clin. Nutr. 2011, 94, 1754S-1758S. [CrossRef] [PubMed]

7. Dennery, P.A. Oxidative stress in development: Nature or nurture? Free Radic. Biol. Med. 2010, 49, $1147-1151$. [CrossRef]

8. Thompson, L.P.; Al-Hasan, Y. Impact of oxidative stress in fetal programming. J. Pregnancy 2012, $2012,582748$. [CrossRef]

9. Hsu, C.N.; Tain, Y.L. Early-life programming and reprogramming of adult kidney disease and hypertension: The interplay between maternal nutrition and oxidative stress. Int. J. Mol. Sci. 2020, 21, 3572. [CrossRef]

10. Tain, Y.L.; Hsu, C.N. Interplay between oxidative stress and nutrient sensing signaling in the developmental origins of cardiovascular disease. Int. J. Mol. Sci. 2017, 18, 841. [CrossRef]

11. Neha, K.; Haider, M.R.; Pathak, A.; Yar, M.S. Medicinal prospects of antioxidants: A review. Eur. J. Med. Chem. 2019, 178, 687-704. [CrossRef] [PubMed]

12. Hsu, C.N.; Huang, L.T.; Tain, Y.L. Perinatal use of melatonin for offspring health: Focus on cardiovascular and neurological diseases. Int. J. Mol. Sci. 2019, 20, 5681. [CrossRef] [PubMed]

13. Tain, Y.L.; Joles, J.A. Reprogramming: A preventive strategy in hypertension focusing on the kidney. Int. J. Mol. Sci. 2016, 17, 23. [CrossRef] [PubMed]

14. Carter, A.M. Placental oxygen consumption. Part I. In vivo studies-A review. Placenta 2000, 21, S31-S37. [CrossRef]

15. Wilcox, C.S. Reactive oxygen species: Roles in blood pressure and kidney function. Curr. Hypertens. Rep. 2002, 4, 160-166. [CrossRef]

16. Tain, Y.L.; Hsu, C.N. Toxic Dimethylarginines: Asymmetric Dimethylarginine (ADMA) and Symmetric Dimethylarginine (SDMA). Toxins 2017, 9, 92. [CrossRef]

17. Zullino, S.; Buzzella, F.; Simoncini, T. Nitric oxide and the biology of pregnancy. Vascul. Pharmacol. 2018, 110, 71-74. [CrossRef]

18. Jenkins, C.; Wilson, R.; Roberts, J.; Miller, H.; McKillop, J.H.; Walker, J.J. Antioxidants: Their role in pregnancy and miscarriage. Antioxid. Redox Signal. 2000, 2, 623-628. [CrossRef]

19. Stein, A.D.; Zybert, P.A.; van der Pal-de Bruin, K.; Lumey, L.H. Exposure to famine during gestation, size at birth, and blood pressure at age 59 y: Evidence from the Dutch Famine. Eur. J. Epidemiol. 2006, 21, 759-765. [CrossRef]

20. Mamun, A.A.; O'Callaghan, M.; Callaway, L.; Williams, G.; Najman, J.; Lawlor, D.A. Associations of gestational weight gain with offspring body mass index and blood pressure at 21 years of age: Evidence from a birth cohort study. Circulation 2009, 119, 1720-1727. [CrossRef]

21. Hosaka, M.; Asayama, K.; Staessen, J.A.; Ohkubo, T.; Hayashi, K.; Tatsuta, N.; Kurokawa, N.; Satoh, M.; Hashimoto, T.; Hirose, T.; et al. Breastfeeding leads to lower blood pressure in 7-year-old Japanese children: Tohoku Study of Child Development. Hypertens. Res. 2013, 36, 117-122. [CrossRef] [PubMed]

22. Oken, E.; Huh, S.Y.; Taveras, E.M.; Rich-Edwards, J.W.; Gillman, M.W. Associations of maternal prenatal smoking with child adiposity and blood pressure. Obes. Res. 2005, 13, 2021-2028. [CrossRef] [PubMed]

23. Fraser, A.; Nelson, S.M.; Macdonald-Wallis, C.; Sattar, N.; Lawlor, D.A. Hypertensive disorders of pregnancy and cardiometabolic health in adolescent offspring. Hypertension 2013, 62, 614-620. [CrossRef] 
24. Williams, D.M.; Fraser, A.; Fraser, W.D.; Hyppönen, E.; Davey Smith, G.; Deanfield, J.; Hingorani, A.; Sattar, N.; Lawlor, D.A. Associations of maternal 25-hydroxyvitamin D in pregnancy with offspring cardiovascular risk factors in childhood and adolescence: Findings from the Avon Longitudinal Study of Parents and Children. Heart 2013, 99, 1849-1856. [CrossRef]

25. Huxley, R.R.; Shiell, A.W.; Law, C.M. The role of size at birth and postnatal catch-up growth in determining systolic blood pressure: A systematic review of the literature. J. Hypertens. 2000, 18, 815-831. [CrossRef] [PubMed]

26. De Jong, F.; Monuteaux, M.C.; van Elburg, R.M.; Gillman, M.W.; Belfort, M.B. Systematic review and meta-analysis of preterm birth and later systolic blood pressure. Hypertension 2012, 59, 226-234. [CrossRef]

27. Barker, D.J.; Bagby, S.P.; Hanson, M.A. Mechanisms of disease: In utero programming in the pathogenesis of hypertension. Nat. Clin. Pract. Nephrol. 2006, 2, 700-707. [CrossRef]

28. Paixão, A.D.; Alexander, B.T. How the kidney is impacted by the perinatal maternal environment to develop hypertension. Biol. Reprod. 2013, 89, 144. [CrossRef]

29. Tain, Y.L.; Chan, S.H.H.; Chan, J.Y.H. Biochemical basis for pharmacological intervention as a reprogramming strategy against hypertension and kidney disease of developmental origin. Biochem. Pharmacol. 2018, 153, 82-90. [CrossRef]

30. Tain, Y.L.; Huang, L.T.; Hsu, C.N.; Lee, C.T. Melatonin therapy prevents programmed hypertension and nitric oxide deficiency in offspring exposed to maternal caloric restriction. Oxid. Med. Cell Longev. 2014, 2014, 283180. [CrossRef]

31. Tain, Y.Y.; Lee, W.C.; Hsu, C.N.; Lee, W.C.; Huang, L.T.; Lee, C.T.; Lin, C.Y. Asymmetric dimethylarginine is associated with developmental programming of adult kidney disease and hypertension in offspring of streptozotocin-treated mothers. PLoS ONE 2013, 8, e55420. [CrossRef] [PubMed]

32. Xiao, D.; Huang, X.; Li, Y.; Dasgupta, C.; Wang, L.; Zhang, L. Antenatal Antioxidant Prevents Nicotine Mediated Hypertensive Response in Rat Adult Offspring. Biol. Reprod. 2015, 93, 66. [CrossRef] [PubMed]

33. Shirpoor, A.; Nemati, S.; Ansari, M.H.; Ilkhanizadeh, B. The protective effect of vitamin E against prenatal and early postnatal ethanol treatment-induced heart abnormality in rats: A 3-month follow-up study. Int. Immunopharmacol. 2015, 26, 72-79. [CrossRef] [PubMed]

34. Tain, Y.L.; Hsu, C.N.; Lee, C.T.; Lin, Y.J.; Tsai, C.C. N-Acetylcysteine Prevents Programmed Hypertension in Male Rat Offspring Born to Suramin-Treated Mothers. Biol. Reprod. 2016, 95, 8. [CrossRef]

35. Tain, Y.L.; Lin, Y.J.; Sheen, J.M.; Yu, H.R.; Tiao, M.M.; Chen, C.C.; Tsai, C.C.; Huang, L.T.; Hsu, C.N. High fat diets sex-specifically affect the renal transcriptome and program obesity, kidney injury, and hypertension in the offspring. Nutrients 2017, 9, 357. [CrossRef]

36. Tain, Y.L.; Wu, K.L.; Lee, W.C.; Leu, S.; Chan, J.Y. Maternal fructose-intake-induced renal programming in adult male offspring. J. Nutr. Biochem. 2015, 26, 642-650. [CrossRef]

37. Koleganova, N.; Piecha, G.; Ritz, E.; Becker, L.E.; Müller, A.; Weckbach, M.; Nyengaard, J.R.; Schirmacher, P.; Gross-Weissmann, M.L. Both high and low maternal salt intake in pregnancy alter kidney development in the offspring. Am. J. Physiol. Renal Physiol. 2011, 301, F344-F354. [CrossRef]

38. Tain, Y.L.; Chan, J.Y.H.; Lee, C.T.; Hsu, C.N. Maternal melatonin therapy attenuates methyl-donor diet-induced programmed hypertension in male adult rat offspring. Nutrients 2018, 10, 1407. [CrossRef]

39. Gambling, L.; Dunford, S.; Wallace, D.I.; Zuur, G.; Solanky, N.; Srai, K.S.; McArdle, H.J. Iron deficiency during pregnancy affects post-natal blood pressure in the rat. J. Physiol. 2003, 552, 603-610. [CrossRef]

40. Tomat, A.; Elesgaray, R.; Zago, V.; Fasoli, H.; Fellet, A.; Balaszczuk, A.M.; Schreier, L.; Costa, M.A.; Arranz, C. Exposure to zinc deficiency in fetal and postnatal life determines nitric oxide system activity and arterial blood pressure levels in adult rats. Br. J. Nutr. 2010, 104, 382-389. [CrossRef]

41. Schlegel, R.N.; Moritz, K.M.; Paravicini, T.M. Maternal hypomagnesemia alters renal function but does not program changes in the cardiovascular physiology of adult offspring. J. Dev. Orig. Health Dis. 2016, 7, 473-480. [CrossRef] [PubMed]

42. Gwathmey, T.M.; Shaltout, H.A.; Rose, J.C.; Diz, D.I.; Chappell, M.C. Glucocorticoid-induced fetal programming alters the functional complement of angiotensin receptor subtypes within the kidney. Hypertension 2011, 57, 620-626. [CrossRef] [PubMed]

43. Giussani, D.A.; Camm, E.J.; Niu, Y.; Richter, H.G.; Blanco, C.E.; Gottschalk, R.; Blake, E.Z.; Horder, K.A.; Thakor, A.S.; Hansell, J.A.; et al. Developmental programming of cardiovascular dysfunction by prenatal hypoxia and oxidative stress. PLoS ONE 2012, 7, e31017. [CrossRef] 
44. Hsu, C.N.; Lin, Y.J.; Tain, Y.L. Maternal exposure to bisphenol a combined with high-fat diet-induced programmed hypertension in adult male rat offspring: Effects of resveratrol. Int. J. Mol. Sci. 2019, 20, 4382. [CrossRef] [PubMed]

45. Hsu, C.N.; Lin, Y.J.; Lu, P.C.; Tain, Y.L. Maternal resveratrol therapy protects male rat offspring against programmed hypertension induced by TCDD and dexamethasone exposures: Is it relevant to aryl hydrocarbon receptor? Int. J. Mol. Sci. 2018, 19, 2459. [CrossRef]

46. Cambonie, G.; Comte, B.; Yzydorczyk, C.; Ntimbane, T.; Germain, N.; Lê, N.L.; Pladys, P.; Gauthier, C.; Lahaie, I.; Abran, D.; et al. Antenatal antioxidant prevents adult hypertension, vascular dysfunction, and microvascular rarefaction associated with in utero exposure to a low-protein diet. Am. J. Physiol. Regul. Integr. Comp. Physiol. 2007, 292, R1236-R1245. [CrossRef]

47. Resende, A.C.; Emiliano, A.F.; Cordeiro, V.S.; de Bem, G.F.; de Cavalho, L.C.; de Oliveira, P.R.; Neto, M.L.; Costa, C.A.; Boaventura, G.T.; de Moura, R.S. Grape skin extract protects against programmed changes in the adult rat offspring caused by maternal high-fat diet during lactation. J. Nutr. Biochem. 2013, 24, 2119-2126. [CrossRef]

48. Tain, Y.L.; Lee, W.C.; Wu, K.L.H.; Leu, S.; Chan, J.Y.H. Targeting arachidonic acid pathway to prevent programmed hypertension in maternal fructose-fed male adult rat offspring. J. Nutr. Biochem. 2016, 38, 86-92. [CrossRef]

49. Nimse, S.B.; Palb, D. Free radicals, natural antioxidants, and their reaction mechanisms. RSC. Adv. 2015, 5, 27986-28006. [CrossRef]

50. Hurrell, R.F. Influence of vegetable protein sources on trace element and mineral bioavailability. J. Nutr. 2003, 133, 2973S-2977S. [CrossRef]

51. John, J.H.; Ziebland, S.; Yudkin, P.; Roe, L.S.; Neil, H.A. Effects of fruit and vegetable consumption on plasma antioxidant concentrations and blood pressure: A randomised controlled trial. Lancet 2002, 359, 1969-1974. [CrossRef]

52. Parikh, A.; Lipsitz, S.R.; Natarajan, S. Association between a DASH-like diet and mortality in adults with hypertension: Findings from a population-based follow-up study. Am. J. Hypertens. 2009, 22, 409-416. [CrossRef] [PubMed]

53. Cicero, A.F.; Colletti, A. Nutraceuticals and blood pressure control: Results from clinical trials and meta-analyses. High Blood Press. Cardiovasc. Prev. 2015, 22, 203-213. [CrossRef] [PubMed]

54. Kizhakekuttu, T.J.; Widlansky, M.E. Natural antioxidants and hypertension: Promise and challenges. Cardiovasc. Ther. 2010, 28, e20-e32. [CrossRef]

55. Baker, J.; Kimpinski, K. Role of melatonin in blood pressure regulation: An adjunct anti-hypertensive agent. Clin. Exp. Pharmacol. Physiol. 2018, 45, 755-766. [CrossRef]

56. Bonnefont-Rousselot, D. Resveratrol and cardiovascular diseases. Nutrients 2016, 8, 250. [CrossRef] [PubMed]

57. Schneider, M.P.; Delles, C.; Schmidt, B.M.; Oehmer, S.; Schwarz, T.K.; Schmieder, R.E.; John, S. Superoxide scavenging effects of $\mathrm{N}$-acetylcysteine and vitamin $\mathrm{C}$ in subjects with essential hypertension. Am. J. Hypertens. 2005, 18, 1111-1117. [CrossRef] [PubMed]

58. Dawson, M.I. The importance of vitamin A in nutrition. Curr. Pharm. Des. 2000, 6, 311-325. [CrossRef]

59. Dimitries, B. Sources of natural phenolic antioxidant. Trends Food Sci. Technol. 2006, 17, 505-512. [CrossRef]

60. Urquiaga, I.; Leighton, F. Plant polyphenol antioxidants and oxidative stress. Biol. Res. 2000, 33, 55-64. [CrossRef]

61. Croft, K.D. The Chemistry and Biological effects of flavonoids and phenolic acids. Ann. N. Y. Acad. Sci. 1998, 854, 435-442. [CrossRef] [PubMed]

62. Wu, G.; Morris, S.M., Jr. Arginine metabolism: Nitric oxide and beyond. Biochem. J. 1998, 336, 1-17. [CrossRef] [PubMed]

63. Salehi, B.; Berkay Yılmaz, Y.; Antika, G.; Boyunegmez Tumer, T.; Fawzi Mahomoodally, M.; Lobine, D.; Akram, M.; Riaz, M.; Capanoglu, E.; Sharopov, F.; et al. Insights on the Use of $\alpha$-Lipoic Acid for Therapeutic Purposes. Biomolecules 2019, 9, 356. [CrossRef] [PubMed]

64. Sharifi-Rad, M.; Anil Kumar, N.V.; Zucca, P.; Varoni, E.M.; Dini, L.; Panzarini, E.; Rajkovic, J.; Tsouh Fokou, P.V.; Azzini, E.; Peluso, I.; et al. Lifestyle, Oxidative Stress, and Antioxidants: Back and Forth in the Pathophysiology of Chronic Diseases. Front. Physiol. 2020, 11, 694. [CrossRef]

65. Pereira, N.; Naufel, M.F.; Ribeiro, E.B.; Tufik, S.; Hachul, H. Influence of Dietary Sources of Melatonin on Sleep Quality: A Review. J. Food Sci. 2020, 85, 5-13. [CrossRef] 
66. Burns, J.; Yokota, T.; Ashihara, H.; Lean, M.E.; Crozier, A. Plant foods and herbal sources of resveratrol. J. Agric. Food Chem. 2002, 50, 3337-3340. [CrossRef] [PubMed]

67. Mokhtari, V.; Afsharian, P.; Shahhoseini, M.; Kalantar, S.M.; Moini, A. A Review on Various Uses of N-Acetyl Cysteine. Cell J. 2017, 19, 11-17.

68. Schwarzenberg, S.J.; Georgieff, M.K.; Committee on Nutrition. Advocacy for Improving Nutrition in the First 1000 Days to Support Childhood Development and Adult Health. Pediatrics 2018, 141, e20173716. [CrossRef]

69. Haider, B.A.; Bhutta, Z.A. Multiple-micronutrient supplementation for women during pregnancy. Cochrane Database Syst. Rev. 2017, 4, CD004905. [CrossRef]

70. Jackson, A.A.; Dunn, R.L.; Marchand, M.C.; Langley-Evans, S.C. Increased systolic blood pressure in rats induced by a maternal low-protein diet is reversed by dietary supplementation with glycine. Clin. Sci. 2002, 103, 633-639. [CrossRef]

71. Tain, Y.L.; Huang, L.T.; Lee, C.T.; Chan, J.Y.; Hsu, C.N. Maternal citrulline supplementation prevents prenatal $\mathrm{N}^{\mathrm{G}}$-nitro-L-arginine-methyl ester (L-NAME)-induced programmed hypertension in rats. Biol. Reprod. 2015, 92, 7. [CrossRef] [PubMed]

72. Tain, Y.L.; Sheen, J.M.; Chen, C.C.; Yu, H.R.; Tiao, M.M.; Kuo, H.C.; Huang, L.T. Maternal citrulline supplementation prevents prenatal dexamethasone-induced programmed hypertension. Free Radic. Res. 2014, 48, 580-586. [CrossRef]

73. Koeners, M.P.; van Faassen, E.E.; Wesseling, S.; Sain-van der Velden, M.; Koomans, H.A.; Braam, B.; Joles, J.A. Maternal supplementation with citrulline increases renal nitric oxide in young spontaneously hypertensive rats and has long-term antihypertensive effects. Hypertension 2007, 50, 1077-1084. [CrossRef] [PubMed]

74. Roysommuti, S.; Lerdweeraphon, W.; Malila, P.; Jirakulsomchok, D.; Wyss, J.M. Perinatal taurine alters arterial pressure control and renal function in adult offspring. Adv. Exp. Med. Biol. 2009, 643, 145-156.

75. Thaeomor, A.; Teangphuck, P.; Chaisakul, J.; Seanthaweesuk, S.; Somparn, N.; Roysommuti, S. Perinatal taurine supplementation prevents metabolic and cardiovascular effects of maternal diabetes in adult rat offspring. Adv. Exp. Med. Biol. 2017, 975, 295-305. [PubMed]

76. Hsu, C.N.; Lin, I.C.; Yu, H.R.; Huang, L.T.; Tiao, M.M.; Tain, Y.L. Maternal Tryptophan Supplementation Protects Adult Rat Offspring against Hypertension Programmed by Maternal Chronic Kidney Disease: Implication of Tryptophan-Metabolizing Microbiome and Aryl Hydrocarbon Receptor. Int. J. Mol. Sci. 2020, 21, 4552. [CrossRef]

77. Fujii, T.; Yura, S.; Tatsumi, K.; Kondoh, E.; Mogami, H.; Fujita, K.; Kakui, K.; Aoe, S.; Itoh, H.; Sagawa, N.; et al. Branched-chain amino acid supplemented diet during maternal food restriction prevents developmental hypertension in adult rat offspring. J. Dev. Orig. Health Dis. 2011, 2, 176-183. [CrossRef] [PubMed]

78. Koeners, M.P.; Racasan, S.; Koomans, H.A.; Joles, J.A.; Braam, B. Nitric oxide, superoxide and renal blood flow autoregulation in SHR after perinatal L-arginine and antioxidants. Acta Physiol. 2007, 190, 329-338. [CrossRef]

79. Koeners, M.P.; Braam, B.; van der Giezen, D.M.; Goldschmeding, R.; Joles, J.A. Perinatal micronutrient supplements ameliorate hypertension and proteinuria in adult fawn-hooded hypertensive rats. Am. J. Hypertens. 2020, 23, 802-808. [CrossRef]

80. Racasan, S.; Braam, B.; van der Giezen, D.M.; Goldschmeding, R.; Boer, P.; Koomans, H.A.; Joles, J.A. Perinatal L-arginine and antioxidant supplements reduce adult blood pressure in spontaneously hypertensive rats. Hypertension 2004, 44, 83-88. [CrossRef]

81. Franco Mdo, C.; Ponzio, B.F.; Gomes, G.N.; Gil, F.Z.; Tostes, R.; Carvalho, M.H.; Fortes, Z.B. Micronutrient prenatal supplementation prevents the development of hypertension and vascular endothelial damage induced by intrauterine malnutrition. Life Sci. 2009, 85, 327-333. [CrossRef] [PubMed]

82. Wang, J.; Yin, N.; Deng, Y.; Wei, Y.; Huang, Y.; Pu, X.; Li, L.; Zheng, Y.; Guo, J.; Yu, J.; et al. Ascorbic Acid Protects against Hypertension through Downregulation of ACE1 Gene Expression Mediated by Histone Deacetylation in Prenatal Inflammation-Induced Offspring. Sci. Rep. 2016, 6, 39469. [CrossRef] [PubMed]

83. Torrens, C.; Brawley, L.; Anthony, F.W.; Dance, C.S.; Dunn, R.; Jackson, A.A.; Poston, L.; Hanson, M.A. Folate supplementation during pregnancy improves offspring cardiovascular dysfunction induced by protein restriction. Hypertension 2006, 47, 982-987. [CrossRef] [PubMed] 
84. Vieira, L.D.; Farias, J.S.; de Queiroz, D.B.; Cabral, E.V.; Lima-Filho, M.M.; Sant'Helena, B.R.M.; Aires, R.S.; Ribeiro, V.S.; Santos-Rocha, J.; Xavier, F.E.; et al. Oxidative stress induced by prenatal LPS leads to endothelial dysfunction and renal haemodynamic changes through angiotensin II/NADPH oxidase pathway: Prevention by early treatment with $\alpha$-tocopherol. Biochim. Biophys. Acta Mol. Basis Dis. 2018, 1864, 3577-3587. [CrossRef]

85. Tain, Y.L.; Lin, Y.J.; Chan, J.Y.H.; Lee, C.T.; Hsu, C.N. Maternal melatonin or agomelatine therapy prevents programmed hypertension in male offspring of mother exposed to continuous light. Biol. Reprod. 2017, 97, 636-643. [CrossRef]

86. Tain, Y.L.; Lee, C.T.; Chan, J.Y.; Hsu, C.N. Maternal melatonin or N-acetylcysteine therapy regulates hydrogen sulfide-generating pathway and renal transcriptome to prevent prenatal N(G)-Nitro-L-arginine-methyl ester (L-NAME)-induced fetal programming of hypertension in adult male offspring. Am. J. Obstet. Gynecol. 2016, 215, 636. [CrossRef]

87. Tain, Y.L.; Leu, S.; Wu, K.L.; Lee, W.C.; Chan, J.Y. Melatonin prevents maternal fructose intake-induced programmed hypertension in the offspring: Roles of nitric oxide and arachidonic acid metabolites. J. Pineal Res. 2014, 57, 80-89. [CrossRef]

88. Tain, Y.L.; Leu, S.; Lee, W.C.; Wu, K.L.H.; Chan, J.Y.H. Maternal Melatonin Therapy Attenuated Maternal High-Fructose Combined with Post-Weaning High-Salt Diets-Induced Hypertension in Adult Male Rat Offspring. Molecules 2018, 23, 886. [CrossRef]

89. Tain, Y.L.; Chen, C.C.; Sheen, J.M.; Yu, H.R.; Tiao, M.M.; Kuo, H.C.; Huang, L.T. Melatonin attenuates prenatal dexamethasone-induced blood pressure increase in a rat model. J. Am. Soc. Hypertens. 2014, 8, $216-226$. [CrossRef]

90. Tain, Y.L.; Sheen, J.M.; Yu, H.R.; Chen, C.C.; Tiao, M.M.; Hsu, C.N.; Lin, Y.J.; Kuo, K.C.; Huang, L.T. Maternal Melatonin Therapy Rescues Prenatal Dexamethasone and Postnatal High-Fat Diet Induced Programmed Hypertension in Male Rat Offspring. Front. Physiol. 2015, 6, 377. [CrossRef]

91. Lee, S.K.; Sirajudeen, K.N.; Sundaram, A.; Zakaria, R.; Singh, H.J. Effects of antenatal, postpartum and post-weaning melatonin supplementation on blood pressure and renal antioxidant enzyme activities in spontaneously hypertensive rats. J. Physiol. Biochem. 2011, 67, 249-257. [CrossRef] [PubMed]

92. Tain, Y.L.; Lee, W.C.; Wu, K.L.H.; Leu, S.; Chan, J.Y.H. Resveratrol Prevents the Development of Hypertension Programmed by Maternal Plus Post-Weaning High-Fructose Consumption through Modulation of Oxidative Stress, Nutrient-Sensing Signals, and Gut Microbiota. Mol. Nutr. Food Res. 2018, 30, e1800066. [CrossRef] [PubMed]

93. Chen, H.E.; Lin, Y.J.; Lin, I.C.; Yu, H.R.; Sheen, J.M.; Tsai, C.C.; Huang, L.T.; Tain, Y.L. Resveratrol prevents combined prenatal $\mathrm{N}^{\mathrm{G}}$-nitro-L-arginine-methyl ester (L-NAME) treatment plus postnatal high-fat diet induced programmed hypertension in adult rat offspring: Interplay between nutrient-sensing signals, oxidative stress and gut microbiota. J. Nutr. Biochem. 2019, 70, 28-37. [CrossRef]

94. Care, A.S.; Sung, M.M.; Panahi, S.; Gragasin, F.S.; Dyck, J.R.; Davidge, S.T.; Bourque, S.L. Perinatal Resveratrol Supplementation to Spontaneously Hypertensive Rat Dams Mitigates the Development of Hypertension in Adult Offspring. Hypertension 2016, 67, 1038-1044. [CrossRef] [PubMed]

95. Tai, I.H.; Sheen, J.M.; Lin, Y.J.; Yu, H.R.; Tiao, M.M.; Chen, C.C.; Huang, L.T.; Tain, Y.L. Maternal Nacetylcysteine therapy regulates hydrogen sulfide-generating pathway and prevents programmed hypertension in male offspring exposed to prenatal dexamethasone and postnatal high-fat diet. Nitric Oxide 2016, 53, 6-12. [CrossRef]

96. Hsu, C.N.; Hou, C.Y.; Chang-Chien, G.P.; Lin, S.; Tain, Y.L. Maternal N-Acetylcysteine therapy prevents hypertension in spontaneously hypertensive rat offspring: Implications of hydrogen sulfide-generating pathway and gut microbiota. Antioxidants 2020, 9, 856. [CrossRef]

97. Gray, C.; Vickers, M.H.; Segovia, S.A.; Zhang, X.D.; Reynolds, C.M. A maternal high fat diet programmes endothelial function and cardiovascular status in adult male offspring independent of body weight, which is reversed by maternal conjugated linoleic acid (CLA) supplementation. PLoS ONE 2015, 10, e0115994.

98. Gregório, B.M.; Souza-Mello, V.; Mandarim-de-Lacerda, C.A.; Aguila, M.B. Maternal fish oil supplementation benefits programmed offspring from rat dams fed low-protein diet. Am. J. Obstet. Gynecol. 2008, 199, 82.e1-82.e7.

99. Sengupta, P. The Laboratory Rat: Relating Its Age with Human's. Int. J. Prev. Med. 2013, 4, 624-630.

100. Ali, S.S.; Ahsan, H.; Zia, M.K.; Siddiqui, T.; Khan, F.H. Understanding oxidants and antioxidants: Classical team with new players. J. Food Biochem. 2020, 44, e13145. [CrossRef] 
101. Takemoto, Y. Amino acids that centrally influence blood pressure and regional blood flow in conscious rats. J. Amino Acids 2012, 2012, 831759. [CrossRef] [PubMed]

102. Hsu, C.N.; Tain, Y.L. Regulation of nitric oxide production in the developmental programming of hypertension and kidney disease. Int. J. Mol. Sci. 2019, 20, 681. [CrossRef] [PubMed]

103. Cynober, L.; Moinard, C.; De Bandt, J.P. The 2009 ESPEN Sir David Cuthbertson. Citrulline: A new major signaling molecule or just another player in the pharmaconutrition game? Clin. Nutr. 2010, 29, 545-551. [CrossRef] [PubMed]

104. Boucknooghe, T.; Remacle, C.; Reusens, B. Is taurine a functional nutrient? Curr. Opin. Clin. Nutr. Metab. Care 2006, 9, 728-733. [CrossRef]

105. Abebe, W.; Mozaffari, M.S. Role of taurine in the vasculature: An overview of experimental and human studies. Am. J. Cardiovasc. Dis. 2011, 1, 293-311.

106. Militante, J.D.; Lombardini, J.B. Treatment of hypertension with oral taurine: Experimental and clinical studies. Amino Acids 2002, 23, 381-393. [CrossRef]

107. Houston, M.C. The role of cellular micronutrient analysis, nutraceuticals, vitamins, antioxidants and minerals in the prevention and treatment of hypertension and cardiovascular disease. Ther. Adv. Cardiovasc. Dis. 2010, 4, 165-183. [CrossRef]

108. Azzi, A.; Ricciarelli, R.; Zingg, J.M. Non-antioxidant molecular functions of alpha-tocopherol (vitamin E). FEBS Lett. 2002, 519, 8-10. [CrossRef]

109. Bjelakovic, G.; Nikolova, D.; Gluud, L.L.; Simonetti, R.G.; Gluud, C. Antioxidant supplements for prevention of mortality in healthy participants and patients with various diseases. Cochrane Database Syst. Rev. 2012, 3, CD007176. [CrossRef]

110. Azaïs-Braesco, V.; Pascal, G. Vitamin A in pregnancy: Requirements and safety limits. Am. J. Clin. Nutr. 2000, 71, 1325S-1333S. [CrossRef]

111. Hardeland, R.; Tan, D.X.; Reiter, R.J. Kynuramines, metabolites of melatonin and other indoles: The resurrection of an almost forgotten class of biogenic amines. J. Pineal Res. 2009, 47, 109-126. [CrossRef] [PubMed]

112. Chen, Y.C.; Sheen, J.M.; Tiao, M.M.; Tain, Y.L.; Huang, L.T. Roles of melatonin in fetal programming in compromised pregnancies. Int. J. Mol. Sci. 2013, 14, 5380-5401. [CrossRef] [PubMed]

113. Voiculescu, S.E.; Zygouropoulos, N.; Zahiu, C.D.; Zagrean, A.M. Role of melatonin in embryo fetal development. J. Med. Life 2014, 7, 488-492.

114. Tain, Y.L.; Huang, L.T.; Chan, J.Y. Transcriptional regulation of programmed hypertension by melatonin: An epigenetic perspective. Int. J. Mol. Sci. 2014, 15, 18484-18495. [CrossRef] [PubMed]

115. Reiter, R.J.; Mayo, J.C.; Tan, D.X.; Sainz, R.M.; Alatorre-Jimenez, M.; Qin, L. Melatonin as an antioxidant: Under promises but over delivers. J. Pineal Res. 2016, 61, 253-278. [CrossRef]

116. Foley, H.M.; Steel, A.E. Adverse events associated with oral administration of melatonin: A critical systematic review of clinical evidence. Complement. Ther. Med. 2019, 42, 65-81. [CrossRef]

117. Hoebert, M.; van der Heijden, K.B.; van Geijlswijk, I.M.; Smits, M.G. Long-term follow-up of melatonin treatment in children with ADHD and chronic sleep onset insomnia. J. Pineal Res. 2009, 47, 1-7. [CrossRef]

118. Sadowsky, D.W.; Yellon, S.; Mitchell, M.D.; Nathanielsz, P.W. Lack of effect of melatonin on myometrial electromyographic activity in the pregnant sheep at 138-142 days gestation (term $=147$ days gestation). Endocrinology 1991, 128, 1812-1818. [CrossRef]

119. Frémont, L. Biological effects of resveratrol. Life Sci. 2000, 66, 663-673. [CrossRef]

120. Baur, J.A.; Sinclair, D.A. Therapeutic potential of resveratrol: The in vivo evidence. Nat. Rev. Drug Discov. 2006, 5, 493-506. [CrossRef]

121. Diaz-Gerevini, G.T.; Repossi, G.; Dain, A.; Tarres, M.C.; Das, U.N.; Eynard, A.R. Beneficial action of resveratrol: How and why? Nutrition 2016, 32, 174-178. [CrossRef] [PubMed]

122. Truong, V.L.; Jun, M.; Jeong, W.S. Role of resveratrol in regulation of cellular defense systems against oxidative stress. Biofactors 2018, 44, 36-49. [CrossRef] [PubMed]

123. Tain, Y.L.; Hsu, C.N. Developmental programming of the metabolic syndrome: Can we reprogram with resveratrol? Int. J. Mol. Sci. 2018, 19, 2584. [CrossRef]

124. Cottart, C.H.; Nivet-Antoine, V.; Laguillier-Morizot, C.; Beaudeux, J.L. Resveratrol bioavailability and toxicity in humans. Mol. Nutr. Food Res. 2010, 54, 7-16. [CrossRef] [PubMed] 
125. Shaito, A.; Posadino, A.M.; Younes, N.; Hasan, H.; Halabi, S.; Alhababi, D.; Al-Mohannadi, A.; Abdel-Rahman, W.M.; Eid, A.H.; Nasrallah, G.K.; et al. Potential Adverse Effects of Resveratrol: A Literature Review. Int. J. Mol. Sci. 2020, 21, 2084. [CrossRef]

126. Calabrese, E.J.; Mattson, M.P.; Calabrese, V. Resveratrol commonly displays hormesis: Occurrence and biomedical significance. Hum. Exp. Toxicol. 2010, 29, 980-1015. [CrossRef]

127. Šalamon, ك̌.; Kramar, B.; Marolt, T.P.; Poljšak, B.; Milisav, I. Medical and Dietary Uses of N-Acetylcysteine. Antioxidants 2019, 8, 111.

128. Kimura, H. The physiological role of hydrogen sulfide and beyond. Nitric Oxide 2014, 41, 4-10. [CrossRef]

129. Van Goor, H.; van den Born, J.C.; Hillebrands, J.L.; Joles, J.A. Hydrogen sulfide in hypertension. Curr. Opin. Nephrol. Hypertens. 2016, 25, 107-113. [CrossRef]

130. Vasdev, S.; Singal, P.; Gill, V. The antihypertensive effect of cysteine. Int. J. Angiol. 2009, 18, 7-21. [CrossRef]

131. Koba, K.; Yanagita, T. Health benefits of conjugated linoleic acid (CLA). Obes. Res. Clin. Pract. 2014, 8, e525-e532. [CrossRef]

132. Giordano, E.; Visioli, F. Long-chain omega 3 fatty acids: Molecular bases of potential antioxidant actions. Prostaglandins Leukot. Essent. Fatty Acids 2014, 90, 1-4. [CrossRef] [PubMed]

133. Grynberg, A. Hypertension prevention: From nutrients to (fortified) foods to dietary patterns. Focus on fatty acids. J. Hum. Hypertens. 2005, 19, S25-S33. [CrossRef] [PubMed]

134. Uson-Lopez, R.A.; Kataoka, S.; Mukai, Y.; Sato, S.; Kurasaki, M. Melinjo (Gnetum gnemon) seed extract consumption during lactation improved vasodilation and attenuated the development of hypertension in female offspring of fructose-fed pregnant rats. Birth Defects Res. 2018, 110, 27-34. [CrossRef] [PubMed]

135. Villanueva, C.; Kross, R.D. Antioxidant-induced stress. Int. J. Mol. Sci. 2012, 13, 2091-2109. [CrossRef]

136. Salehi, B.; Martorell, M.; Arbiser, J.L.; Sureda, A.; Martins, N.; Maurya, P.K.; Sharifi-Rad, M.; Kumar, P.; Sharifi-Rad, J. Antioxidants: Positive or Negative Actors? Biomolecules 2018, 8, 124. [CrossRef]

137. Tain, Y.L.; Hsu, C.N. Targeting on asymmetric dimethylarginine related nitric oxide-reactive oxygen species imbalance to reprogram the development of hypertension. Int. J. Mol. Sci. 2016, 17, 2020. [CrossRef]

138. Beltowski, J.; Kedra, A. Asymmetric dimethylarginine (ADMA) as a target for pharmacotherapy. Pharmacol. Rep. 2006, 58, 159-178.

139. Fan, N.C.; Tsai, C.M.; Hsu, C.N.; Huang, L.T.; Tain, Y.L. N-acetylcysteine prevents hypertension via regulation of the ADMA-DDAH pathway in young spontaneously hypertensive rats. BioMed Res. Int. 2013, 2013, 696317. [CrossRef]

140. Tain, Y.L.; Huang, L.T.; Lin, I.C.; Lau, Y.T.; Lin, C.Y. Melatonin prevents hypertension and increased asymmetric dimethylarginine in young spontaneous hypertensive rats. J. Pineal Res. 2010, 49, 390-398. [CrossRef]

141. Te Riet, L.; van Esch, J.H.; Roks, A.J.; van den Meiracker, A.H.; Danser, A.H. Hypertension: Renin-angiotensin aldosterone system alterations. Circ. Res. 2015, 116, 960-975. [CrossRef] [PubMed]

142. Kett, M.M.; Denton, K.M. Renal programming: Cause for concern? Am. J. Physiol. Regul. Integr. Comp. Physiol. 2011, 300, R791-R803. [CrossRef] [PubMed]

143. Hsu, C.N.; Lee, C.T.; Huang, L.T.; Tain, Y.L. Aliskiren in early postnatal life prevents hypertension and reduces asymmetric dimethylarginine in offspring exposed to maternal caloric restriction. J. Renin Angiotensin Aldosterone Syst. 2015, 16, 506-513. [CrossRef] [PubMed]

144. Sherman, R.C.; Langley-Evans, S.C. Antihypertensive treatment in early postnatal life modulates prenatal dietary influences upon blood pressure in the rat. Clin. Sci. 2000, 98, 269-275. [CrossRef]

145. Tain, Y.L.; Lin, Y.J.; Sheen, J.M.; Lin, I.C.; Yu, H.R.; Huang, L.T.; Hsu, C.N. Resveratrol prevents the combined maternal plus postweaning high-fat-diets-induced hypertension in male offspring. J. Nutr. Biochem. 2017, 48, 120-127. [CrossRef]

146. Hsu, C.N.; Lin, Y.J.; Yu, H.R.; Lin, I.C.; Sheen, J.M.; Huang, L.T.; Tain, Y.L. Protection of male rat offspring against hypertension programmed by prenatal dexamethasone administration and postnatal high-fat diet with the nrf2 activator dimethyl fumarate during pregnancy. Int. J. Mol. Sci. 2019, 20, 3957. [CrossRef]

147. Efeyan, A.; Comb, W.C.; Sabatini, D.M. Nutrient-sensing mechanisms and pathways. Nature 2015, 517, 302-310. [CrossRef]

148. Tain, Y.L.; Hsu, C.N.; Chan, J.Y. PPARs link early life nutritional insults to later programmed hypertension and metabolic syndrome. Int. J. Mol. Sci. 2016, 17, 20. [CrossRef] [PubMed] 
149. Sugden, M.C.; Caton, P.W.; Holness, M.J. PPAR control: It's SIRTainly as easy as PGC. J. Endocrinol. 2010, 204, 93-104. [CrossRef]

150. Hsu, C.N.; Hou, C.Y.; Lee, C.T.; Chan, J.Y.H.; Tain, Y.L. The interplay between maternal and post-weaning high-fat diet and gut microbiota in the developmental programming of hypertension. Nutrients 2019, 11, 1982. [CrossRef]

151. Tain, Y.L.; Hsu, C.N. AMP-activated protein kinase as a reprogramming strategy for hypertension and kidney disease of developmental origin. Int. J. Mol. Sci. 2018, 19, 1744.

152. Hu, Y.; Chen, D.; Zheng, P.; Yu, J.; He, J.; Mao, X.; Yu, B. The Bidirectional interactions between resveratrol and gut microbiota: An insight into oxidative stress and inflammatory bowel disease therapy. BioMed Res. Int. 2019, 2019, 5403761. [PubMed]

153. Kong, Y.; Olejar, K.J.; On, S.L.W.; Chelikani, V. The Potential of Lactobacillus spp. for Modulating Oxidative Stress in the Gastrointestinal Tract. Antioxidants 2020, 9, 610.

154. Chu, D.M.; Meyer, K.M.; Prince, A.L.; Aagaard, K.M. Impact of maternal nutrition in pregnancy and lactation on offspring gut microbial composition and function. Gut Microbes 2016, 7, 459-470. [PubMed]

155. Nicholson, J.K.; Holmes, E.; Kinross, J.; Burcelin, R.; Gibson, G.; Jia, W.; Pettersson, S. Host-gut microbiota metabolic interactions. Science 2012, 336, 1262-1267.

156. Al Khodor, S.; Reichert, B.; Shatat, I.F. The Microbiome and Blood Pressure: Can Microbes Regulate Our Blood Pressure? Front. Pediatr. 2017, 5, 138.

157. Hsu, C.N.; Hou, C.Y.; Chan, J.Y.H.; Lee, C.T.; Tain, Y.L. Hypertension programmed by perinatal high-fat diet: Effect of maternal gut microbiota-targeted therapy. Nutrients 2019, 11, 2908.

158. Hsu, C.N.; Lin, Y.J.; Hou, C.Y.; Tain, Y.L. Maternal administration of probiotic or prebiotic prevents male adult rat offspring against developmental programming of hypertension induced by high fructose consumption in pregnancy and lactation. Nutrients 2018, 10, 1229.

159. Wan, X.; Guo, H.; Liang, Y.; Zhou, C.; Liu, Z.; Li, K.; Niu, F.; Zhai, X.; Wang, L. The physiological functions and pharmaceutical applications of inulin: A review. Carbohydr. Polym. 2020, 246, 116589.

Publisher's Note: MDPI stays neutral with regard to jurisdictional claims in published maps and institutional affiliations.

(C) 2020 by the authors. Licensee MDPI, Basel, Switzerland. This article is an open access article distributed under the terms and conditions of the Creative Commons Attribution (CC BY) license (http://creativecommons.org/licenses/by/4.0/). 